\title{
Tourism Challenges and the Opportunities for Sustainability: A Case Study of Grenada, Barbados, and Tobago
}

\author{
Helen M. Bhola-Paul \\ St. George’s University, Grenada
}

\begin{abstract}
Tourists travel to the islands of Grenada, Barbados, and Tobago to bask in the sun of these islands' pristine beaches. This resulting business of tourism provides the catalyst for these host countries to deliver a valuable holiday experience and the dichotomy of the negative impacts created by the very tourism industry. This paper presents three islands whose reliance on the tourism industry has stimulated economic growth, socio-cultural benefits, and environmental preservation along with the negative impacts of environmental degradation, cultural dilution, and economic leakages. Key to this research is the management of those challenges through sustainable tourism opportunities involving various stakeholders and their role in minimizing economic leakages, social inequity, and environmental degradation.
\end{abstract}

Keywords: tourism, excursionist, foreign tourist, sustainability, multiplier effect

\section{Tourism's Viability in Small Island Developing States (SIDS)}

The United Nations World Tourism Organization (UNWTO, 2015) forecasted that international tourism, from 2010 to 2015, would have an increase of $4 \%$ every year. This growth was confirmed in the first quarter of 2015 with the Caribbean having the second highest growth of 7\% by sub-region (UNWTO, 2015). According to the World Travel and Tourism Council (WTTC, 2015), travel and tourism contributes 9.8\% to the world's GDP with 105 million people directly employed, representing 9.4\% of the world's employment and sustains more jobs than the automotive, manufacturing, and the chemical industries. Tourism's contribution to Grenada’s GDP was US\$0.161 billion in 2010 (WTTC, 2012). Tobago's tourism industry contributed US\$186.5 million to its GDP in 2009 (T. Bahadur, personal communication, 2012). Barbados tourism industry contributed US\$1,912 billion in 2010 to its GDP (WTTC, 2012). Tourism's economic viability and the failed agricultural industries of these Caribbean islands make tourism the last resort for survival (Pattullo, 2005). According to Bishop (2010), the liberalization of the global political economy and the resulting decimation of agriculture as an export have led SIDS to be pushed towards tourism. The hospitality of the Caribbean people creates an opportunity to deliver an authentic "island experience" by many SIDS, such as Grenada, Barbados, and Tobago. According to Montero (2011, p. 23), "The Caribbean has been considered by the West as a place to be discovered, conquered, and possessed environmentally, socially, and economically". The tourism industry holds great promise of visitor interaction with the local community, social benefits, and the showcasing of various cultural attributes unique to these islands. The increasing

Helen M. Bhola-Paul, assistant professor, Department of Business and Management Studies, St. George’s University. Email: hbhola@sgu.edu. 
reliance on tourism creates economic growth for these islands and the dependent industries through economic linkages. Tourism's growth beyond exception brings with it inherent social, environmental, and economic inequity which if not properly managed can be damaging to these islands. The dependence on tourism by Grenada, Barbados, and Tobago has resulted in numerous benefits and has created challenges for these islands. The objectives of this research paper are to:

(1) Describe the benefits created by the tourism industry for Grenada, Barbados, and Tobago;

(2) Describe the challenges associated with the tourism industry economically, socio-culturally, and environmentally;

(3) Recommend sustainable strategies to manage the tourism industry.

\section{An Overview of the Tourism Industry}

Mathieson and Wall (1982, p. 1) purported that tourism is "the temporary movement of people to destinations outside their normal places of work and residence, the activities undertaken during their stay in those destinations, and the facilities created to cater to their needs". The movement of persons can be further clarified by categorizing them into "excursionists" and "foreign tourists". Mathieson and Wall (1982, p. 11) argued that amongst the many definitions for an excursionist and a tourist in the literature, "the United Nations Conference on Travel and Tourism in Rome in 1963 describes tourist as persons staying for at least 24 hours in the country visited and the excursionist staying for less than 24 hours in the country visited". Gordon (2013) argued that excursionists can be described based on their motivation for travel which is to engage in nostalgic oriented experiences. Oh and Schuett (2010, p. 43) purported that, "Excursionist motives are for challenges, physical fitness, and recovering from everyday stress whilst the tourist seeks activities for pleasure such as driving, hunting, fishing, and watching wildlife”. The Caribbean is a destination that is frequented by both excursionists and tourists in search of a sun, sand, and sea experience. The resulting movement of these persons creates tourism-related activities in islands such as Grenada, Barbados, and Tobago, as they seek to benefit from the much needed foreign exchange the tourism industry has to proffer. Goeldner and Brent Ritchie (2009) purported that tourism is the sum of the phenomena and relationships when the tourists interact with business suppliers, host governments, and host communities in the process of retaining these tourists. Tourism, according to Goeldner and Brent Ritchie (2009), can be argued as the sum of commerce that is generated through the interactions between the tourists and the various sectors of a country. SIDS such as Grenada, Barbados, and Tobago through their tourism industries have created that interaction through business suppliers and the host government and they have benefitted from the resulting financial exchanges.

Grenada is a small island north of Trinidad and Tobago, which is located in the southern Caribbean and it has been dependent on the tourism industry as a sustainable economic industry. The tourism industry has socially impacted the island with the growth in cultural events and festivals highlighting the unique afro-Caribbean heritage of Grenada. The economic ramifications of the tourism industry have been profound with the increase in tourism development projects, employment, and investment on the island. The tourism industry has created challenges economically through overdependence on the industry, excess demands on the island's resources, and economic leakages. Environmentally, it creates a strain on the island's natural resources and socially the effects of cultural dilution, and local perception of economic inequalities. 
Barbados, an island located north of Grenada, has been dependent on tourism for over many years. It both offers a rich cultural heritage based on its African heritage and brings numerous excursionists and foreign tourists to their shores on an annual basis. The island has been the producer of numerous world renowned festivals including their "Crop Over" Festival and Jazz Festival. Its environmental attractions include their natural caves, beaches, and marine life and economically have benefitted from the tourism industry through the construction of new buildings, development of tourism entities such as hotels, mariners, golf courses, and entertainment businesses and the resulting employment created by these entities. Barbados has been subjected to economic challenges such as unequal distribution of the economic benefits accrued from tourism. Environmentally, the tourism industry has created an overdependence on the island's limited natural resources and social anarchy through changing values and lifestyles of its people.

Tobago, a small Caribbean island south of Grenada, has had a booming tourism industry for the past two decades. Numerous major airlines stop off at the island and it has benefited from continual international hotel expansion. As a SIDS, its economy relies heavily on tourism for its survival. The economic viability of the tourism industry depends on the environmental preservation of the island's natural reefs and beaches and the socio-cultural protection of its events and festivals. This reliance on tourism for its sustenance makes it imperative for Tobago to have policies to direct their tourism development and to alleviate any damages caused by the tourism industry.

\section{Tourism as a Developmental Strategy}

\section{Grenada}

As an island of 344 sq. km and a population of 108,419, the island of Grenada has been an agricultural economy for many years (Central Intelligence Agency, 2012). As an agricultural destination for many decades, Grenada proved to be unsuccessful in surviving the challenges of the global agricultural market with the removal of preferential prices once offered by the EU's single market. Bananas were the main agricultural crop at that time for the island. Added to that lost was the devastation to the agricultural sector by two hurricanes, Ivan in 2004 and Emily in 2005, resulting in a reliance on tourism as the most viable export product. Grenada's tourism development has been on a small scale as compared to larger Caribbean islands such as Jamaica and the Bahamas, with the focus being on niches such as eco-tourism, yachting, sailing, and agricultural tourism.

Economically, the benefits accrued from tourism included its impact on arrivals to the island, contribution to the GDP, and its contribution to employment. Grenada's stop-over arrivals for 2011 January-October were 94,770 (Caribbean Tourism Organization, 2012). Their stay-over arrivals for the year 2010 amounted to 112,939 visitors (Grenada Board of Tourism, 2010). Grenada's GDP is greatly dependent on tourism. Tourism contributed $24.5 \%$ in 2009 and $23.8 \%$ in 2010 to its GDP and US $\$ 0.158$ billion in 2009 and US $\$ 0.161$ billion in 2010 to its GDP (WTTC, 2012). Grenada's tourism industry's total contribution to employment was $22.7 \%$ in 2009, 22\% in 2010, and 22.3\% in 2011 (WTTC, 2012).

Socio-culturally, Grenada's tourism has been responsible for the continued development and sustainability of its carnival festival which occurs in August annually with hotels, communities, taxis, and local businesses relying on the economic activities generated from this event. Maroon and String band, Parang and Saraka festivals all continue to grow due to the increasing support from the tourism industry. The communities are more economically stable due to their participation in tourism-related activities (Weaver, 2001). The health care and education have improved due to the impact of tourism on the economy (N. Joseph, personal communication, January 20, 2012). 
Environmentally, tourism has provided protection to the natural environment through financial contribution from entrance fees and the maintenance and enhancement from government funding. The financial contribution from tourism has provided for the management and expansion of protected areas such as some of Grenada's underwater marine parks Molinere and Dragon Bay (N. Joseph, personal communication, January 20, 2012).

\section{Barbados}

Barbados has been an island whose history emerged from the plantation period where it cultivated sugar cane and exported rum with molasses and sugar as their main export. In the 1990s, tourism became a significant industry for Barbados making it the main export product. It is one of the most easterly Caribbean islands, with a land mass size of 430 sq. km and a population of 286,705 (Central Intelligence Agency, 2012). Barbados's niche tourism includes sports, events, festival, and cruise tourism. The primary sporting events are cricket and horse racing. Barbados is host to numerous events and festivals such as its annual jazz festival and "Crop Over" Carnival contributing to increased foreign tourist arrivals. Cruise tourism is a major niche with numerous cruise calls made on the island on a daily basis.

Tourism is a significant export product for the island and contributes economically to the island through its GDP, the employment it provides, and the number of cruise calls made by the excursionists and the foreign tourist stop-over arrivals. Barbados's stop-over arrivals for 2011 January-October were 465,575 (Caribbean Tourism Organization, 2012). Barbados's tourism contribution to its GDP was 45.7\% in 2009 and $46.6 \%$ in 2010 to its GDP and US\$1,651 billion in 2009 and US\$1,912 billion in 2010 to its GDP (WTTC, 2012). Barbados tourism industry's total contribution to employment was $45.3 \%$ in $2009,46.2 \%$ in 2010 , and $46.6 \%$ in 2011 (WTTC, 2012). Cruise passenger arrivals to the island were 597,526 in 2008 with 425 cruise calls and 635,746 in 2009 with 460 cruise calls (Caribbean Tourism Organization, 2012).

Socio-culturally, tourism has impacted Barbados through its standard of living, and the visitors' interest in their local culture giving rise to opportunities for exposure of their talents. The "Crop Over" Carnival festival occurs annually during the months of July-August and hotels, restaurants, local businesses, and government benefit from the influx of foreign tourists attending this event. One of the well-known Caribbean jazz festivals is the one hosted by Barbados annually during the month of January. The exposure of these events to their foreign tourists creates opportunities for preservation and conservation of their heritage.

The natural environment of Barbados continues to develop as a result of its tourism industry. One of the natural attractions of Barbados is its Harrison's Cave, which is made up of stalactite and stalagmite crystals naturally formed within the caves, attracting numerous tourists on a daily basis. Its marine life and the display of its marine life is experienced through an underwater submarine journey. Tourist visiting such environmental phenomena contributes to its sustainability and preservation.

\section{Tobago}

Tobago, the sister island to Trinidad and commonly referred to as Trinidad and Tobago, is dependent on tourism whilst its sister island Trinidad's primary exports are natural gas and petroleum. It has a collective population of 1.2 million people between the two islands and a size of 1,528 sq. km. Tobago's tourism industry has been a growing industry since 1990 and the island is well known for its tranquility and its relative low crime rate (Central Intelligence Agency, 2012). Tobago's niche tourism includes leisure tourism, events, and festivals which include its annual Jazz festival and eco-tourism with the island having a great barrier reef known as "Buccoo Reef”. 
Tourism's economic contribution to Tobago is significant and it is the major export product of the island. The number of Tobago stay-over tourists for half of 2010 (the period of January-July) was 16,625 (T. Bahadur, personal communication, 2012). Tourist arrivals to the island for 2008 were 432,551 and in 2009 were 371,889, a decrease from 2008. Tobago's tourism industry contributed US $\$ 186.5$ million to its GDP in 2009 (T. Bahadur, personal communication, 2012). The number of cruise passengers to the island in 2008 was 48,666 and in 2009 was 119,600, resulting in an increase in 2009 (Caribbean Tourism Organization, 2012).

Socio-culturally, tourism has impacted Tobago through its heritage festival. It occurs from the middle of July to early August annually. The events that take place are categorized into village shows and committee shows. The village shows are put on by various villages in Tobago. The various villages have signature shows that they do every year. The heritage of that island is very sacred to the people, as such; everyone gets involved in the festival and also protects its authenticity. Tobago features its own Jazz festival and would feature both local and foreign artists at this event, and attracts an increased number of visitors every year.

Environmentally, as a small island when compared to its sister island of Trinidad, it has two major environmental phenomena: one is the Great Barrier Reef, called "Buccoo Reef”, featuring an array of marine and plant life. Strong emphasis is placed on visitors observing and not removing any of the plant and animal life found there; the other is its Nylon pool which features a serene turquoise swimming area in the middle of the ocean. Tobago as an island is relatively small to Trinidad; however, the dependence on tourism is critical, because it does not have the resources such as natural gas and petroleum like its sister island Trinidad. The tourism experience is extended to their visitors through education, observation, participation, and their financial contribution through entrance fees charged to experience these natural attractions (Weaver, 2001).

\section{Challenges of the Tourism Industry}

Goeldner and Brent Ritchie (2009) purported that tourism is a phenomenon with the relationships arising from the interaction of tourists, business suppliers, host governments, and host communities in the process of attracting and hosting these tourists resulting in economic activities generated by the industry itself. Tourism is described as an export product which is "a good or service manufactured or provided in one country that is purchased by a person or business from another country” (Cook, Yale, \& Marqua, 2010, p. 279). As an export it adds money to one economy and that money is deducted from another economy (Cook, Yale, \& Marqua, 2010, p. 279). According to Archer (1972), tourism spending diffused through an economy with the multiplier effect with many other sectors gaining secondary benefits from that initial circulation. Every purchase made locally by the foreign tourists or excursionists enters the economy of the island and it circulates through purchases made, salaries paid to tourism employees, and money spent by the tourism employees in local shops and businesses resulting in the multiplier effect. Mathieson and Wall (1982) argued that the multiplier effect provides countries with information on the short-term economic impacts of the tourist expenditure, hereby identifying the weak linkages, the areas of the economy benefitting the most and those needing stimulation. The foreign tourists and excursionists take their purchasing power and transfer it to the economies of Grenada, Barbados, and Tobago, and these islands benefit from it as it circulates within their economies (Cook et al., 2010). To attract tourists, these islands' business suppliers, host governments, and host communities must import the necessary products and services and pay the necessary salaries to foreign agencies to promote and market the island. The resulting high importation of products creates poor linkages resulting in high leakages. Mathieson and Wall (1982, p. 82) argued that, "The extent to which strong linkages can be established with 
local entrepreneurs depends on the type of suppliers and producers the industry demands and the ability of the suppliers to meet those demands". These resulting activities create a negative effect to the multiplier effect and instead generate economic leakages. The Caribbean is known for its high "economic leakages" averaging around $70 \%$, which means that for every dollar earned from the foreign tourists and excursionists, 70 cents is lost to the importation of goods and services (Pattullo, 1996).

The tourism industry's viability is based on its natural environment. The environment encompasses air, land, and water. The foreign tourists and excursionists' primary interest in Grenada, Barbados, and Tobago is for its climate, sea, and white sand beaches (Pattullo, 1996). In Grenada, the replacing of mangroves with tourism development is a reflection of disregard for the environment. In the northern area of Grenada, the Levera development project was the habitat for unusual birds and plant species which was compromised for that development. Barbados has had major problems with its beach erosions, water pollution and litter, and as the former director of Caribbean Tourism Organization Jean Holder said in 1993 before a London Audience, “As the place sinks under the weight of social friction and solid waste, all tourists exit” (Pattullo, 1996, p. 106). In Tobago, there is a problem with sand mining used in the development of tourism projects. In the 1980s, their airport extension and deep water harbour in Scarborough, the capital was done through sand mining from their beaches. Today, their beach "Goldsborough is a lot narrower and is littered with rotting trees and plants and not used by the tourist or the locals anymore” (Pattullo, 1996, p. 109).

Socio-culturally, tourism can be a means for social engagement with the intangible heritage of Grenada, Barbados, and Tobago. United Nations Educational, Scientific, and Cultural Organization (UNESCO, 2003) in its Convention for the Safeguarding of the Intangible Cultural Heritage identified intangible culture as "practices, representations, expressions". Intangible clearly delineates something that you experience on the contrary to tangible where it can entail an object, construction, or architecture of a more material nature (Pearce, 2009). The Caribbean islands are known for their rich intangible culture reflected in their African heritage and portrayed in their dances, folklore, songs, dress, and dialect. Tourist perception of Caribbean music is often that of salsa, reggae, and calypso, but there are many other forms of musical expression that exist. In Grenada's sister island Carriacou, a unique musical expression is its "Big Drum Dancing” (Pattullo, 1996, p. 183). To the tourists, however, they would never experience it, since the calypso music is what is portrayed as the music of Grenada. This unique form of musical expression is becoming lost resulting in cultural dilution. The commercialization of festivals offered to the foreign tourists and excursionists can be seen with Barbados "Crop Over" Festival which is a celebration of the end of the sugar cane harvest. Traditionally, before 1940, it would be portrayed using relics from the sugar plantation such as carts decorated with flowers bearing the last of the sugar cane. This festival died by 1940 and was revived by the Board of Tourism in 1964 and became a summer festival. It is featured specifically during the low tourist season in the month of August. This festival no longer has the plantation relics and traditions and has been replaced with calypso and queen shows and a carnival like parade, known as "Kadooment” (Pattullo, 1996, p. 187).

Tourism has brought social inequalities to these islands and they include the high cost for local tourism investment and generation of foreign sex workers. The locals of these islands view the foreign investors as being the real beneficiaries of the industry, with excessive duty-free concession privileges to open hotels and bring in their products. There is also the high cost for energy for persons interested in operating some of the tourism investments, such as hotels and restaurants. In particular, Grenada's cost of electricity is 44 US cents per kilo watt/hour and is further subjected to a 15\% VAT consumption tax (R. Fielden, personal 
communication, January 20, 2012). The problem of sex tourism in Trinidad and Tobago has reflected poorly on their tourism industry. The human traffickers use places like Trinidad and Tobago to bring sex workers who enter illegally and go by undetected. Sex workers are promised lucrative jobs and believe that there will always be a need for their services with a strong tourism industry like Trinidad and Tobago (Sheppard, 2007).

\section{The Tourism Industry Issues of Safeguarding and Sustainability: Grenada, Barbados, and Tobago}

The tourism industry's survival for Grenada, Barbados, and Tobago is contingent on a sustainable tourism approach. According to the UNWTO and UNEP (2005), sustainable tourism is tourism that takes into account the current and future economic, social, and environmental impacts, whilst simultaneously addressing the needs of the visitor, the industry, the environment, and the host community. Swarbrooke (2005) argued that sustainable tourism is tourism activity that meets the needs of tourist, the tourism industry, and host communities today without compromising the ability of other generations to meet their own needs. According to the WTTC (1992), sustainable tourism is in its purest form, an industry which attempts to make a low impact on the environment and local culture, while helping to generate income, employment, and the conservation of local eco-systems. It is responsible tourism which is both ecologically and culturally sensitive. According to WTTC (1992), sustainable tourism must incorporate as part of its mandate low impact on the environment and local culture. Swarbrooke (2005) purported that sustainable tourism satisfies the current needs of tourists, the tourist industry, and the host communities without compromising future generations' needs. Sustainable tourism for these islands is the option and must include the coordination of policies, pro-active planning, acceptance of limitations on growth, educating persons involved and a commitment to a long-term plan by all stakeholders (Butler, 1991). The stakeholders in these islands are the host communities, governments, the tourists, non-governmental organizations (NGOs), the tourism industry, media, experts, and pressure groups (Swarbrooke, 2005). The roles of some of these stakeholders, primarily the host communities, the tourists, the tourism industry, and the governments of Grenada, Barbados, and Tobago are critical in bringing about this change. Host communities include persons "who own tourism enterprises, employed in the local tourism industry, and those whose lives are adversely affected by tourism” (Swarbrooke, 2005, p. 125). Dodds and Butler (2009) argued that failure in sustainable tourism policies is as a result of governments having short-term five-year job creation and growth plans instead of long-term plans that have social and environmental implications. Grenada, Barbados, and Tobago should foster long-term sustainable plans of 10 or more years with short-term goals. Participative decision-making should engage the local communities regarding tourism developments. The use of local knowledge when developing policies for the tourism industry is critical to avoid the erosion of intangible heritage. Avoiding conflicts with the host community and the tourist is critical and can be alleviated by establishing rules for the tourist as they visit and experience these host communities.

The foreign tourists and excursionists who come to Grenada, Barbados, and Tobago do so because of an interest in those islands. These islands have an opportunity to educate their tourists on sensitive issues pertaining to the island, such as littering, mode of dress on the island, taking away artifacts and endangered species from these islands, and this should be communicated to both foreign tourists and the excursionists upon arrival. There is a need for tourists to respect the physical environment and minimize their use of local scarce resources (Swarbrooke, 2005). 
The tourism industry should be involved in voluntary action and self-regulation on issues pertaining to the advancement of environmental initiatives, such as recycling, reusing, and reducing on their consumption. Small islands such as Grenada, Barbados, and Tobago should be avoiding mega developments and focusing on smaller developments that fit the island and not create major strains on the natural limited resources. There are regional and international initiatives that facilitate certifications in various areas such as at a business level, community level, and construction level, and these certifications reward the environmental responsibility of the holders. Some examples of certifications are Green Globe 21, ISO 1400, and Blue Flag for beach cleanliness. Today's travelers are more "green" conscientious and would support countries whose focus is on protecting their environment.

The government is supposed to represent the entire country they manage and not just one particular group. The government has the responsibility for the legislation and regulation they put in place, the need especially in Grenada is to have land use planning. Proper land use planning will avoid the excessive development of one area, such as the southern belt of Grenada with little tourism developments in other areas of the island. All tourism projects and developments should receive the scrutiny of Environmental Impact Assessments (EIA) and Social Impact Assessments (SIA) before they are approved. Governments should have designated special protection to particular areas and the island's heritage. The government should have general control over the tourism industry through ongoing research to improve the industry and reduce its negative impacts economically, socio-culturally, and environmentally.

\section{Managerial Implications}

Goeldner and Brent Ritchie (2009) purported that tourism is the sum of the phenomena through the interaction of tourists, business suppliers, host governments, and host communities in hosting the tourists. The various stakeholders of Grenada, Barbados, and Tobago tourism industry must be involved in developing policies and plans that propel the industry in the direction that fits each island's unique situation.

In the case of Grenada, there is a constant friction between stakeholders recognizing their role and exercising self-regulation in doing what is best for the sustainability of the industry. There seems to be an ongoing concern in Grenada about whether the economic benefit of the industry is ramified amongst its people. There is still discontentment about foreign investors benefiting from the government duty-free concessions, whilst local persons have to pay the duties on imported products. For tourism development to be more sustainable for Grenada, there needs to be more partnership with the host governments, host communities, NGOs, and business suppliers. Tourism plans and policies should receive inputs from all stakeholders. Tourism ventures must provide quality employment for the host communities. A code of practice needs to be established based on internationally accepted standards: The Agenda 21 Principles based on the Earth Summit held in Rio de Janeiro in 1992 can be a starting point through "the need for education and training programs to improve and manage the heritage and natural resources” (Canadian International Development Agency, 2012, p. 7).

Barbados, a more mature tourist destination and one who has had opportunities to learn from mistakes of overdevelopment and poor planning of its tourism industry, continues to find ways to make its industry more sustainable. The Ministry of Tourism and International Transport is responsible for sustainable tourism at the national level. Barbados has a National Tourism Policy, whose broad objective is to pursue sustainable tourism development through improvement and optimal use of human resources and services and through the conservation and managed use of cultural, built and natural heritage, in order to ensure a product of the highest 
quality whilst improving the life and economic development of the people of Barbados (Government of Barbados, 2004). In spite of a National Tourism Policy in Barbados, currently, there are no established procedures to monitor continuously the progress of tourism development. The government ministries play their part in monitoring some activities through agencies such as Physical Development Planning, the Fisheries Act, and the National Conservation Commissions Act. According to Mycoo (2006), there is no sustainable tourism policy or plan per se in Barbados and it is only through direct and indirect government activities that sustainable objectives are being met. Mycoo (2006) argued as well that policy makers have concerns that certification strengthens the already powerful tourism entities and not the local enterprises. Barbados needs to have an integrated approach to tourism planning and management with the combination of urban management such as transportation, land use planning, marketing, economic development, fire, and safety with the need to plan for the tourism industry (Canadian International Development Agency, 2012).

Trinidad and Tobago have developed a 2020 Vision for their tourism industry and the mandate of that vision was focused on "strong promotion, high value, international competitive visitor experience, strong brand recognition, and public and private sector partnership with cultural transformation” (Vision 2020 Tourism Development Plan, 2012). Tourism as an industry offers a comparative advantage to most of the other industries such as manufacturing and agriculture which islands like Grenada, Barbados, and Tobago once depended on. Trinidad and Tobago need to address their tourism industry based on the sustainable economic principles with the partnering of their stakeholders to produce a quality experience for their visitors. In addition, they need to focus on their environmental conservation and their prudent management of natural resources with an emphasis on EIA to evaluate the suitability of tourism developments and the social maintenance and enhancement of the quality of life both inter-generational and intra-generational with an equitable distribution of wealth (Canadian International Development Agency, 2012).

\section{Conclusion}

Tourism for these islands will continue to offer a competitive advantage relative to the other revenue-generating industries. The consequential issues for Grenada, Barbados, and Tobago tourism industries are the sustainability considerations, which should not be driven by their short-term strategic plans but be driven by tourism research through sustainable tourism plans and policies (Mycoo, 2006). Swarbrooke (2005) purported that the focus of tourism must be on the forms of tourism which meet the needs of the tourists, the tourism industry, and the host communities today and for generations in the future. It is imperative that the stakeholders of the various industries use the resources of these islands today without compromising their future generations' ability to use these resources.

\section{References}

Archer, B. H. (1972). The primary and secondary beneficiaries of tourist spending. The Tourist Review, 27(2), 42-45.

Bishop, M. L. (2010). Tourism as a small-state development strategy: Pier pressure in the Eastern Caribbean? Progress in Development Studies, 10(2), 99-114.

Butler, R. W. (1991). Tourism, environment, and sustainable development. Environmental Conservation, 18(3), 201-209.

Canadian International Development Agency. (2012). A manual for community tourism destination management (pp. 6-9). Canadian Universities Consortium, Urban Environmental Management Project, Training and Technology Transfer Program. Retrieved from http://www.ucalgary.ca/uofc/faculties/EV/designresearch/projects/2000/cuc/tp/outreach/destination\%20manual.pdf

Caribbean Tourism Organization. (2012). Tourism arrivals in the Caribbean by destinations (2000-2012). Retrieved from http://www.onecaribbean.org/statistics/2011statistics/default.aspx 
Central Intelligence Agency. (2012). The world factbook. Retrieved from https://www.cia.gov/library/publications/the-world-factbook/geos/gj.html

Cook, R. A., Yale, L. J., \& Marqua, J. J. (2010). Tourism: The business of travel (4th ed.). New York, NY: Van Nostrand Reinhold Company.

Dodds, R., \& Butler, R. (2009). Barriers to implementing sustainable tourism policy in mass tourism destinations. TOURISMOS: An International Multidisciplinary Journal of Tourism, 5(1), 35-53.

Goeldner, C. R., \& Brent Ritchie, J. R. (2009). Tourism: Principles, practices, philosophies (11th ed.). Hoboken, NJ: John Wiley \& Sons.

Gordon, K. O. (2013). Emotion and memory in nostalgia sport tourism: Examining the attraction to postmodern ballparks through an interdisciplinary lens. Journal of Sport and Tourism, 18(3), 217-239.

Government of Barbados. (2004). The Barbados sustainable development policy: "Doing the right things by doing things right". National Commission on Sustainable Development. Retrieved from http://www.un.org/esa/dsd/dsd_aofw_ni/ni_pdfs/NationalReports/barbados/BarbadosSustainableDevelopmentPolicy.pdf

Grenada Board of Tourism. (2010). Grenada Board of Tourism arrival statistics 2010. Government of Grenada Printers.

Mathieson, A., \& Wall, G. (1982). Tourism: Economic, physical, and social impacts. Essex, UK: Longman House.

Montero, C. G. (2011). On tourism and the constructions of "paradise islands" in Central America and the Caribbean. Bulletin of Latin American Research, 30(1), 21-34.

Mycoo, M. (2006). Sustainable tourism using regulations, market mechanisms, and green certification: A case study of Barbados. Journal of Sustainable Tourism, 14(5), 489-511.

Oh, J. J., \& Schuett, M. A. (2010). Exploring expenditure-based segmentation for rural tourism: Overnight stay visitors versus excursionists to fee-fishing sites. Journal of Travel and Tourism Marketing, 27(1), 31-50.

Pattullo, P. (1996). Last resorts: The cost of tourism in the Caribbean. Kingston, Jamaica: Ian Randle Publication.

Pattullo, P. (2005). Last resorts: The cost of tourism in the Caribbean (2nd ed.). New York, NY: New York University Press.

Pearce, S. (2009). Constructing intangible heritage. Barcelos, Portugal: Green Lines Institute.

Sheppard, S. (2007, August 5). Sex tourism drives illicit trade, experts say. Trinidad and Tobago Newsday. Retrieved from http://www.newsday.co.tt/news/0,61837.html

Swarbrooke, J. (2005). Sustainable tourism management. Wallingford, UK. CABI Publishing.

United Nations Educational, Scientific, and Cultural Organization [UNESCO]. (2003). Convention for the safeguarding of the intangible cultural heritage. October 17, 2003, UNESCO. Retrieved from http://portal.unesco.org/en/ev.phpURL_ID=17716\&URL_DO=DO_TOPIC\&URL_SECTION=201.html

United Nations World Tourism Organization [UNWTO]. (2015). International tourist arrivals up 4\% in the first four months of 2015. Retrieved from http://media.unwto.org/press-release/2015-07-08/international-tourist-arrivals-4-first-four-months-2015

UNWTO and UNEP. (2005). Making tourism more sustainable: A guide for policy makers. UNWTO, Madrid and UNEP, Paris.

Vision $2020 \quad$ Tourism Development Plan. (2012). $\quad$ Retrieved from http://www.tourism.gov.tt/LinkClick.aspx?fileticket=wXAnNsb2Kjw\%3d\&tabid=95

Weaver, D. (2001). Ecotourism. Melbourne, Australia: John Wiley \& Sons.

World Travel and Tourism Council [WTTC]. (2012). Economic research monthly updates. Retrieved from http://www.wttc.org/research/economic-impact-research/country-reports/g/grenada/

World Travel and Tourism Council [WTTC]. (2015). Benchmarking travel and tourism. Retrieved from http://www.wttc.org/-/media/files/reports/benchmark\%20reports/regional\%20results\%202015/global\%20benchmarking\%20r eport\%202015.pdf 